LINGUA, Vol. 16, No. 1, Maret 2019

p ISSN: 1979 9411; e ISSN: 2442 238X

Http://lingua.pusatbahasa.or.id; Email: presslingua@gmail.com

Center of Language and Cultural Studies, Surakarta, Indonesia

Sultana, Rusdiawan \& Gunayasa, K. Bagus Ida. 2019. Fungsi Cerita Rakyat Sabuk Bidadari dalam Masyarakat Suku Sasak. Lingua (2019), 16(1): 109 122. DOI: 10.30957/lingua.v16i1.578.

\title{
FUNGSI CERITA RAKYATSABUK BIDADARI \\ DALAM MASYARAKAT SUKU SASAK
}

\author{
Sultana, Rusdiawan \& Ida Bagus Kade Gunayasa \\ Magister Pendidikan Bahasa Indonesia \\ Fakultas Keguruan dan Ilmu Pendidikan \\ Universitas Mataram \\ Corrsponding e-mail: yudhayudi0406@gmail.com
}

\begin{abstract}
This study explores the oral story of the Sasak tribe "The Angel Belt". As a literary work, especially oral literature or Sasak stories this study posed that Sasak literary works not only function as an entertainment, or bedtime, but it leads to the low public aspiration of the region's literature. The research questions of this study were what functions are identified in the folk tales of Angel Belt in Sasak society in Bujak village Batukliang sub-district? This research constituted a descriptive qualitative which described the existence of functions and seen in the story, behavior character, and motivation or action in the role of each character in a story. The analysis began with the determination of informants, data collection data analysis then draw a conclusion. The results show that in the story "Angel Belt" contained the function as follows: a) as a projection system, namely collective reflection tools, b) as a means of consolation, c) as an educational tool, d) as a tool of criticism.
\end{abstract}

Keywords: function, folk, Angel Belt

DOI: $10.30957 /$ lingua.v16i1.578.

\section{PENDAHULUAN}

Usaha menggali khasanah budaya Nusantara bukan saja melalui pengumpulan barang-barang material yang merupakan hasil kerajinan masyarakat, tetapi juga dapat dilakukan melalui penelitian hasil karya sastra.

Sastra merupakan suatu karya yang cukup menarik dalam pengungkapan ide dan perasaan pada dunia karya modern saat ini. Sastra itu sendiri merupakan pencerminan dari kehidupan masyarakat. Melalui karya sastra tersebut, pengarang dapat mengungkapkan kehidupan masyarakat, hal ini sesuai yang dikatakan Hudson bahwa, karya sastra sebagai pengungkapan baku dari apa yang direnungkan dan dirasakan mengenai segi-segi yang menarik minat secara langsung dan kuat yang pada dasarnya karya sastra merupakan ungkapan keindahan melalui bentuk bahasa. (Sayuti, 1988:8)

Dilihat dari kurun waktu dan hasil sastranya, kesusastraan Indonesia terbagi atas kesusastraan lama dan kesastraan baru. Kesusastraan lama adalah semua karya sastra yang dihasilkan sebelum masuknya bangsa Eropa serat kebudayaannya di Indonesia. 
LINGUA, Vol. 16, No. 1, Maret 2019

p ISSN: 1979 9411; e ISSN: 2442 238X

Http://lingua.pusatbahasa.or.id; Email: presslingua@gmail.com

Center of Language and Cultural Studies, Surakarta, Indonesia

Sultana, Rusdiawan \& Gunayasa, K. Bagus Ida. 2019. Fungsi Cerita Rakyat Sabuk Bidadari dalam Masyarakat Suku Sasak. Lingua (2019), 16(1): 109 122. DOI: 10.30957/lingua.v16i1.578.

Masuknya bangsa Eropa ke Indonesia diperkirakan awal abad ke sembilan belas (Sulhan, 2006:57).

Bila dicermati, karya sastra merupakan intisari sosial yang menggunakan bahasa sebagai medianya. Sastra menyajikan berbagai sisi kehidupan dan kehidupan menyajikan kenyataan. Menurut Suyatno (2004:131) bahwa, dengan adanya sastra manusia bisa mengenal kehidupan multidimensialkarena, dapat memberikan pengaruh yang sangat penting untuk mengenal cara berpikir, mengenal baik dan buruk, mengenal yang benar dan salah serta cara hidup sendiri dan masyarakat.

Karya sastra dapat berupa novel, cerpen, puisi, drama dan cerita-cerita rakyat. Novel, puisi, cerpen, drama dan cerita rakyat merupakan hasil yang dominan, tetapi novel dan cerita rakyat amat banyak peminatnya. Karena novel dan cerita rakyat sebagai salah satu bentuk sastra sebagai objek yang dinikmati dan sekaligus dikaji.Dikatakan sebagai objek yang dinikmati sebab, cerita rakyat memeiliki unsur-unsur keindahan dan pesan.

Nilai-nilai yang terkandung dalam sastra dapat dijadikan sebagai cerminan dan tuntunan manusia dalam menjalankan kehidupannya yang tidak dapat dipisahkan dengan lingkungan budaya suatu daerah. Dengan demikian, siapa pun yang ingin mengetahui nilai-nilai yang terkandung di suatu lingkungan kebudayaan, hendaknya mempelajari dengan saksama sastra yang dihasilkan oleh lingkungan kebudayaan tersebut.

Masyarakat suku Sasak tempo dulu, dapat dibilang masyarakat yang kreatif dan seni (estetik) karena mampu menghadirkan karya sastra layaknya masyarakat lain di Nusantara ini. Karya sastra yang dihadirkan oleh masyarakat Sasak berupa cerita yang diangkat oleh rakyat suku Sasak cukup banyak. Cerita rakyat yang dimaksud adalah cerita yang tumbuh dan berkembang di tengah-tengah masyarakat suku Sasak. Cerita rakyat banyak mengungkapkan tentang hal-hal gaib di luar kehidupan manusia biasa (Kosasih, 2008:13). Salah satu cerita rakyat Suku Sasak yang banyak menimbulkan versi tentang bentuk, fungsi, dan nilai pendidikan yang terkandung di dalamnya adalah cerita rakyat "Sabuk Bidadari".

Peneliti memilih judul pada cerita rakyat "Sabuk Bidadari" karena cerita rakyat tersebut dapat memberikan makna yang erat kaitannya dengan nilai kehidupan dan nilai kemanusiaan yang diperlukan dan diharapkan pada masyarakat pembaca untuk tujuan pembentuk moral yang lebih baik, sebagaimana dijelaskan Budi Darma dalam artikelnya yang berjudul " Moraldalam Sastra" bahwa karya sastra yang baik selalu memberikan pesan kepada para pembaca untuk berbuat baik. Pesan ini dinamakan Moral. Akhir-akhir ini orang menamakan Amanat maksudnya sama yaitu, karya sastra yang baik selalu mengajak pembaca untuk menjunjung tinggi norma-norma moral.

Edukatif moralitas pada cerita "Sabuk Bidadari" karya tercermin dalam diri dan sikap bidadari sebagai seorang perempuan yang turun dari langit. Sabuk Bidadari sebagai dasar munculnya kecintaan bidadari pada seorang pemuda dan junjungan masyarakat karena kecantikan dan kewibawaan sebagai putri langit. Namun demikian, versi tentang bentuk, fungsi, dan nilai pendidikan yang dimiliki oleh Sabuk Bidadari tersebut belum teriventarisasi dengan jelas dan pasti. Oleh karena itu, perlu dikaji secara 
LINGUA, Vol. 16, No. 1, Maret 2019

p ISSN: 1979 9411; e ISSN: 2442 238X

Http://lingua.pusatbahasa.or.id; Email: presslingua@gmail.com

Center of Language and Cultural Studies, Surakarta, Indonesia

Sultana, Rusdiawan \& Gunayasa, K. Bagus Ida. 2019. Fungsi Cerita Rakyat Sabuk Bidadari dalam Masyarakat Suku Sasak. Lingua (2019), 16(1): 109 122. DOI: 10.30957/lingua.v16i1.578.

teliti dan cermat. Untuk itulah, penulis merasa perlu melakukan kajian tentang "fungsi cerita rakyat sabuk bidadari dalam masyarakat suku Sasak Lombok".

Berdasarkan uraian di atas, ada satu hal yang sangat menarik untuk dijadikan titik landasan permasalahan. Hal tersebut di atas dirumuskan dalam rumusan masalah sebagai berikut: Apa fungsi cerita rakyat Sabuk Bidadari dalam Masyarakat suku Sasak Desa Bujak Kecamatan Batukliang?

\section{LANDASAN TEORI}

\subsection{Konsep dasar}

Kajian adalah mempelajari atau menyelidiki secara rinci. Bentuk merupakan rupa atau wujud. Sedangkan fungsi adalah kegunaan suatu hal (Partanto, 1994:166). Cerita rakyat adalah cerita yang tumbuh dan berkembang di tengah-tengah masyarakat yang banyak mengungkapkan hal-hal gaib di luar kehidupan manusia biasa (Kosasih, 2008:13). Sabuk Bidadari merupakan selendang atau sabuk yang dimiliki bidadari yang turun dari langit dan sebagai penyebab timbulnya rasa cinta kasih antara bidadari dengan pemuda desa yang mengambil sabuk tersebut.

Jadi, kajian fungsi cerita rakyat Sabuk Bidadari yang dimaksud dalam penelitian ini adalah, mempelajari atau menyelidiki kegunaan cerita yang berkembang di tengahtengah masyarakat Sasak Lombok tentang Sabuk Bidadari yang diambil pemuda sebagai dasar timbulnya cinta kasih keduanya.

\subsection{Penelitian yang Relevan}

Penelitian yang berkaitan dengan analisis fungsi cerita rakyat sudah banyak dilakukan. Hanya saja peneliti belum menemukan penelitian terdahulu yang berkaitan dengan cerita rakyat Sabuk Bidadari yang dimiliki oleh masyarakat suku Sasak Lombok. Yang ada adalah penelitian yang dilakukan Mardiana (2008) tentang analisis cerita Latifa Kafirli pada masyarakat Hu'u Kabupaten Dompu yang berlokasi di Hu'u Kabupaten Dompu. Dua puluh keluarga dijadikan sampel penelitian di bawah kriteria kalau istri dan suami merupakan penduduk asli Dompu yang mengetahui tentang cerita Latifa Kafirli. Penelitian tersebut penekanannya lebih mengkaji tentang bentuk, fungsi, dan nilai yang terkandung dalam cerita tersebut. Selain itu, penelitian yang dilakukan Subahan (2002), yang meneliti tentang Kajian cerita rakyat suku Sasak ditinjau dari fungsinya. Penelitian tersebut lebih menekankan dan mengkaji tentang fungsi cerita rakyat suku Sasak bagi kehidupan bermasyarakat secara umum.

Dengan melihat penelitian yang dilakukan tersebut di atas, maka dalam penelitian ini, peneliti lebih menekankan pada fungsi cerita rakyat "Sabuk Bidadari" dalam masyarakat suku Sasak Lombok yang ada di desa Bujak, karena sebelumnya, sepengetahuan peneliti belum pernah ada yang meneliti tentang perihal tersebut.

\subsection{Pengertian Cerita Rakyat}

Cerita rakyat diartikan sebagai tuturan rakyat yang memberitakan bagaimana terjadinya sesuatu hal (peristiwa, kejadiannya). Lebih lanjut dikatakan bahwa cerita merupakan karangan yang menuturkan perbuatan, pengalaman atau penderitaan orang 
LINGUA, Vol. 16, No. 1, Maret 2019

p ISSN: 1979 9411; e ISSN: 2442 238X

Http://lingua.pusatbahasa.or.id; Email: presslingua@gmail.com

Center of Language and Cultural Studies, Surakarta, Indonesia

Sultana, Rusdiawan \& Gunayasa, K. Bagus Ida. 2019. Fungsi Cerita Rakyat Sabuk Bidadari dalam Masyarakat Suku Sasak. Lingua (2019), 16(1): 109 122. DOI: 10.30957/lingua.v16i1.578.

tersebut (baik yang sungguh-sungguh terjadi ataupun yang hanya rekan belaka (Poerwadarminta, 1988:2002).

Di samping itu, ahli mengemukakan bahwa cerita dapat diartikan sebagai lakon yang diwujudkan atau dipertunjukkan dalam gambaran hidup (Alwi 2001:210). Jadi, yang dimaksud dengan cerita dalam penelitian ini adalah tuturan yang memberitakan tentang terjadinya suatu peristiwa baik yang sungguh-sungguh ataupun yang hanya rekaan yang bersumber dari rakyat.

\subsection{Jenis-Jenis Cerita Rakyat}

Ditinjau dari sumbernya, jenis cerita terdiri atas mitos, legenda, dan dongeng. Masing-masing jenis cerita tersebut akan diuraikan sebagai berikut:

\section{Mitos}

Mitos adalah cerita rakyat kuno yang dianggap dapat dipercaya dan bertuah (Partanto, 1994:316). Sedangkan menurut Sulhan Najib (2006:51) menyatakan bahwa, mitos adalah cerita rakyat tentang kepercayaan rakyat di suatu daerah, yang biasanya berisi tentang roh halus, alam gaib dan sebagainya. Jadi, mitos merupakan cerita rakyat kuno yang dianggap dapat dipercaya dan berkaitan roh halus, alam gaib, dan sebagainya. Mitos ditokohkan oleh para dewa atau makhluk setengah dewa, yang peristiwanya terjadi di dunia lain atau di dunia yang bukan dunia yang kita kenal seperti sekarang. Mitos pada umumnya mengisahkan terjadinya alam semesta, dunia pertama, dan sebagainya.

\section{Legenda}

Legenda adalah cerita rakyat yang dianggap oleh para empunya cerita sebagai suatu kejadian yang sungguh-sungguh terjadi berkaitan dengan sejarah (Samsuri, 2006:396). Sedangkan menurut Sulhan Najib (2006:51) bahwa, legenda merupakan cerita rakyat yang berkaitan dengan suatu kejadian alam, asal-usul suatu tempat, atau benda di suatu daerah.

Jadi, legenda adalah cerita rakyat sebagai suatu kejadian yang sungguh-sungguh terjadi yang berkaitan dengan sejarah seperti suatu kejadian alam, asal-usul suatu tempat atau benda di suatu daerah. Legenda bersifat sekuler dan terjadi pada masa yang belum lampau dan bertempat didunia yang kita kenal sekarang. Legenda seringkali dipandang sebagai suatu kisah sejarah kolektif, walaupun sejarah itu sebenarnya tidak tertulis dan telah mengalami distorsi sehingga seringkali jauh berbeda dengan kisah aslinya.

Legenda biasanya bersifat migratoris, yakni dapat berpindah-pindah, sehingga dikenal luas di daerah-daerah yang berbeda. Selain itu legenda acapkali tersebar dalam bentuk pengelompokkan yang disebut siklus, yaitu sekelompok cerita yang berkisar pada suatu tokoh atau suatu kejadian tertentu, misalnya legenda mengenai panji.

\section{Dongeng}

Dongeng adalah cerita rakyat yang lahir dari khayalan pengarangnya (Sulhan Najib, 2006:51). Sedangkan menurut Samsuri (2006:172) bahwa, dongeng adalah kisah yang dituturkan atau ditulis yang biasanya hasil rekaan saja yang sifatnya sebagai 
LINGUA, Vol. 16, No. 1, Maret 2019

p ISSN: 1979 9411; e ISSN: 2442 238X

Http://lingua.pusatbahasa.or.id; Email: presslingua@gmail.com

Center of Language and Cultural Studies, Surakarta, Indonesia

Sultana, Rusdiawan \& Gunayasa, K. Bagus Ida. 2019. Fungsi Cerita Rakyat Sabuk Bidadari dalam Masyarakat Suku Sasak. Lingua (2019), 16(1): 109 122. DOI: 10.30957/lingua.v16i1.578.

hiburan. Jadi, dongeng adalah cerita rakyat yang lahir dari khayalan pengarangnya yang biasanya hasil rekaan saja yang sifatnya sebagai hiburan.

Dongeng hampir terdapat di setiap tempat di dunia ini. Hanya tokoh-tokoh utamanya yang berbeda, misalnya dalam kesusasteraan Belanda yang ditokohi oleh srigala. Sedangkan di Indonesia menggunakan kancil.

\subsection{Kehidupan Cerita Rakyat dalam Masyarakat Sasak}

Kehidupan cerita rakyat dalam masyarakat Sasak sangat terpelihara dengan baik. Hal ini terlihat dari munculnya berbagai cerita-cerita rakyat Sasak yang telah banyak diterbitkan baik berupa mite, dongeng, maupun legenda.

Mite adalah, cerita rakyat yang dianggap benar-benar terjadi serta dianggap suci oleh yang punya cerita. Sedangkan menurut Partanto (1994:316) bahwa, mite merupakan cerita yang berkaitan dengan kepercayaan atau filsafat suatu negara. Di samping itu, Kosasi (2008:43) menyatakan bahwa, mite berisi tentang hal-hal yang gaib seperti dewi, peri, atau Tuhan. Jadi, yang dimaksud dengan mite adalah, cerita rakyat Sasak yang berkaitan dengan kepercayaan dan dianggap benar-benar terjadi. Seperti cerita rakyat Sasak Tegodek-godek.

Legenda adalah, cerita rakyat yang dianggap sebagai suatu kejadian yang sungguh-sungguh pernah terjadi (Bascom, 1985:5). Sedangkan menurut Partanto (1994:285) bahwa legenda adalah, cerita rakyat pada zaman dahulu yang berkaitan dengan sejarah. Di samping itu, Sulhan (2006:51) mengemukakan bahwa legenda adalah cerita rakyat tentang suatu kejadian alam, asal usul suatu tempat atau benda di suatu daerah. Jadi, legenda adalah cerita rakyat Sasak yang dianggap sebagai suatu kejadian yang sungguh-sungguh pernah terjadi pada zaman dahulu tentang suatu kejadian alam, asal-usuk suatu tempat atau benda di suatu daerah. Yang termasuk legenda adalah cerita rakyat putri nyale, putri mandalika, dan lain-lain.

Dongeng adalah cerita yang aneh-aneh dan benar-benar tidak terjadi (Partanto, 1994:134). Sedangkan menurut Sulhan (2006:51) bahwa dongeng merupakan cerita yang lahir dari khayalan pengarangnya yang bersifat rekaan. Di samping itu, Kosasi (2008:18) menyatakan bahwa dongeng itu adalah cerita yang banyak dibumbui dengan hal-hal yang tidak masuk akal tetapi berfungsi sebagai media hiburan dan pendidikan karena memiliki pesan-pesan yang berguna bagi kehidupan sehari-hari. Jadi, dongeng adalah cerita yang aneh-aneh dan benar-benar tidak terjadi yang lahir dari khayalan pengarangnya dan berfungsi sebagai media hiburan dan pendidikan karena memiliki pesan-pesan yang berguna bagi kehidupan sehari-hari. Yang termasuk dongeng adalah cerita rakyat Sabuk Bidadari

\subsection{Teori Fungsi}

Fungsi adalah kegunaan sesuatu hal (Partanto, 1994:166). Jadi, fungsi cerita berarti kegunaan suatu cerita yang bersifat positif dan bisa mendidik serta membentuk kepribadian individu para pembaca. Menurut Bascom (1985:20) terdapat empat fungsi cerita rakyat antara lain: (1) Sebagai sistem proyeksi, yaitu sebagai alat pencerminan angan-angan secara kolektif, (2) Sebagai alat pengesahan pranata-pranata dan lembaga- 
LINGUA, Vol. 16, No. 1, Maret 2019

p ISSN: 1979 9411; e ISSN: 2442 238X

Http://lingua.pusatbahasa.or.id; Email: presslingua@gmail.com

Center of Language and Cultural Studies, Surakarta, Indonesia

Sultana, Rusdiawan \& Gunayasa, K. Bagus Ida. 2019. Fungsi Cerita Rakyat Sabuk Bidadari dalam Masyarakat Suku Sasak. Lingua (2019), 16(1): 109 122. DOI: 10.30957/lingua.v16i1.578.

lembaga kebudayaan, (3) Sebagai alat pendidikan anak, dan (4) Sebagai alat pemaksa dan pengawas agar norma-norma masyarakat selalu dipatuhi anggota kolektifnya.

Di sisi lain, Nurhayati (1999:25) mengemukakan bahwa secara umum cerita rakyat berfungsi sebagai: (1) Sebagai alat hiburan, (2) Sebagai alat pengajaran, (3) Untuk membiasakan masyarakat menggunakan kata-kata yang indah, (4) Untuk menumbuhkan di kalangan masyarakat keupayaan mengenal dan mengapresiasi sastera, dan (5) Dasar penciptaan karya sastera baru.

\section{METODE}

\subsection{Objek Penelitian}

Objek penelitian adalah sesuatu yang menjadi pembicaraan dalam suatu penelitian (Samsuri, 2006:443). Sedangkan, menurut Partanto (1994:335) bahwa, objek penelitia adalah hal atau orang yang menjadi pokok pembicaraan atau sasaran. Dengan demikian, maka objek penelitian yang dimaksud dalam penelitian ini adalah fungsi cerita rakyat Sabuk Bidadari dalam masyarakat suku Sasak Lombok yang ada di desa Bujak.

\subsection{Data}

Data dalam penelitian ini, diperoleh dari informan yang mengetahui tentang halhal yang berkaitan dengan Sabuk Bidadari dalam masyarakat Sasak. Informan tersebut adalah Ketua RT dan tokoh adat di Dusun Gunung Petung Desa Bujak Kecamatan Batukliuang Kecamatan Batukliang Kabupaten Lombok Tengah.

Sebagaimana tujuan dari penelitian ini adalah untuk mengetahui fungsi cerita rakyat Sabuk Bidadari dalam Masyarakat suku Sasak Lombok, maka data dapat dibagi menjadi 2 macam antara lain:

a. Data kualitatif yaitu, data yang digambarkan dengan kata-kata atau kalimat, dan dipisah-pisahkan menurut kategori untuk memperoleh kesimpulan.

b. Data kuantititatif, yaitu jenis data eksperimen yang berjenis interval. Data kuantitatif dapat dibagi dua yaitu data dari variabel deskrit disebut data diskrit, berupa frekuensi, dan data dari variabel kuantum disebut data kuantum berupa ordinal interval, ratio (Arikunto, 2002:89).

Dari pendapat tersebut maka data yang dipergunakan dalam penelitian ini adalah data-data kualitatif yaitu data yang di gambarkan dengan kata-kata atau kalimat dan dipisah-pisahkan menurut kategori untuk memperoleh kesimpulan.

\subsection{Sumber Data}

Sumber data data dalam penelitian ini adalah semua orang Sasak Lombok yang tinggal di Desa Bujak Kecamatan Batukliang Kabupaten Lombok Tengah. Mereka berjumlah 38 orang yang memiliki kriteria sebagai berikut:

a. Orang suku Sasak asli artinya adalah orang suku Sasak.

b. Usia 45 tahun ke atas mereka yang mengetahui tentang cerita Sabuk Bidadari.

c. Memiliki kemampuan untuk memberikan pendapat tentang struktur, fungsi, dan nilai-nilai yang terkandung dalam cerita rakyat Sabuk Bidadari.

d. Tidak pernah meninggalkan tempat dalam waktu yang lama. 


\subsection{Teknik Pengumpulan Data Observasi}

Metode observasi adalah, metode pengumpulan data dengan melakukan pengamatan langsung terhadap obyek yang diteliti (Riyanto Yatim, 2001:96). Metode ini dimaksudkan untuk mengumpulkan data melalui pengamatan secara langsung terhadap objek yang diteliti, dan hal-hal yang diamati peneliti mencakup nama-nama responden, bahasa yang digunakan sehari-hari, cerita yang pernah diketahui, serta aspek lain yang berkaitan dengan struktur, fungsi, dan nilai kandungan cerita rakyat Sabuk Bidadari itu sendiri, sehingga tujuan penelitian ini dapat dicapai dengan baik..

\section{Wawancara}

Selain observasi, pengumpulan data dalam penelitian inidilakukan pula dengan teknik wawancara. Wawancara adalah pengumpulan data yang menghendaki komunikasi langsung antara peneliti dengan subjek atau responden. Dalam wawancara biasanya terjadi wawancara sepihak yang dilakukan secara sistematis dan berpijak pada tujuan penelitian (Arikunto, 2002:131). Peneliti mewawancarai informan yang sifatnya terbuka yakni wawancara tentang hal-hal:

1) Apakah cerita rakyat telah banyak diketahui ?

2) Pernahkah mendengar cerita rakyat Sabuk Bidadari ?

3) Bagaimanakah sesungguhnya cerita rakyat tersebut?

4) Apa sajakah fungsi cerita Sabuk Bidadari di masyarakat pada umumnya? .

Hasil wawancara dicatat secara sistematis dengan menggunakan kertas kosong, sebagai bahan pertimbangan untuk menarik kesimpulan.

\section{Rekaman}

Selain, observasi, dokumentasi, dan wawancara. Pengumpulan data dapat juga delakukan dengan merekam. Rekaman berarti mencetak (Partanto, 1994:392). Jadi merekam yang dimaksud dalam penelitian ini adalah mencetak ke dalam kaset tentang cerita Sabuk Bidadari yang diperoleh melalui subjek penelitian.

\section{Transkripsi}

Di samping rekaman, wawancara dan observasi tersebut di atas, pengumpulan data juga dapat dilakukan dengan transkripsi. Transkripsi berarti pengubahan (penyalinan) teks dari satu ejaan ke ejaan lain dengan tujuan menyarankan lafal bunyi unsur bahasa yang bersangkutan (Partanto, 1994:489). Jadi, transkripsi digunakan untuk menyalin data dalam bentuk ejaan Sasak yang diperoleh melalui subjek penelitian ini.

\section{Telaah Isi}

Telaah isi yang digunakan dalam penelitian ini, karena peneliti ingin berusaha menyelidiki, memeriksa, sekaligus menelaah nilai-nilai yang terkadung dalam cerita rakyat Sabuk Bidadari dalam masyarakat suku Sasak Lombok.

\section{Dokumenter}


LINGUA, Vol. 16, No. 1, Maret 2019

p ISSN: 1979 9411; e ISSN: 2442 238X

Http://lingua.pusatbahasa.or.id; Email: presslingua@gmail.com

Center of Language and Cultural Studies, Surakarta, Indonesia

Sultana, Rusdiawan \& Gunayasa, K. Bagus Ida. 2019. Fungsi Cerita Rakyat Sabuk Bidadari dalam Masyarakat Suku Sasak. Lingua (2019), 16(1): 109 122. DOI: 10.30957/lingua.v16i1.578.

Dokumenter digunakankarena, peneliti ingin berusaha untuk menggali dan mendeskripsikan objek yang akan diteliti secara mendalam. Dokumenter yaitu, suatu cara pengumpulan data dengan melihat atau mengamati serta mengadakan pencatatanpencatatan yang sistimatis. Adapun maksud dari dokumenter dalam penelitian ini adalah untuk mendapatkan dokumen dalam penelitian ini. Sedangkan metode deskriptif yaitu, menggambarkan secara rinci data-data yang diperoleh tanpa direduksi ke dalam ukuranukuran pengangkaan. Langkah-langkah yang dilakukan oleh peneliti ini antara lain:

1) membaca berulang-ulang dan memahami isi teks cerita Sabuk Bidadari

2) mengadakan pengamatan terhadap ide-ide yang mendasari setiap ide-ide satuannya

3) mengadakan penjelajahan terhadap buku-buku acuan yang sesuai

4) menyeleksi data yang sesuai dengan tujuan penelitian yang diterapkan.

\subsection{Teknik Analisis Data}

Dalam penelitian ini, data yang diperoleh dianalisis dengan menggunakan metode kualitatif yaitu suatu pengolahan data yang dilakukan dengan menggambarkan fenomena atau gejala yang terjadi berdasarkan data berupa informasi yang berkenaan dengan pertanyaan apa, mengapa, dan bagaimana yang dianalisis secara induktif agar mengandung makna yang lebih tepat (Sudjana dan Ibrahim, 2004:199). Secara garis besar pelaksanan analisis data meliputi tiga langkah antara lain:

\section{Identifikasi data}

Identifikasi data dalam penelitian ini maksudnya adalah peneliti mengidentifikasi atau memberikan identitas tentang data yang berkaitan dengan cerita rakyat sabuk bidadari yang diperoleh baik melalui observasi, wawancara, dokumentasi maupun data yang peroleh dengan yang lainnya.

\section{Klasifikasi data}

Dari semua data yang diperoleh baik data yang diperoleh, melalui observasi, wawancara, dokumentasi maupun data yang peroleh dengan yang lainnya, peneliti kelompokkan menjadi dua bagian yaitu (1) struktur cerita rakyat sabuk bidadari yang terangkum, dan (2) fungsi cerita rakyat sabuk bidadari yang diperoleh dari berbagai subjek.

\section{Interpretasi data}

Setelah data terkumpul dan sudah dikelompokkan maka dapat disimpulkan tentang struktur dan fungsi cerita rakyat sabuk bidadari dalam masyarakat Suku Sasak Lombok. Dengan demikian dapat diperoleh kesimpulan yang dapat diyakini kebenarannya dengan bukti yang sesuai dengan keadaan di lapangan.

\section{HASIL DAN BAHASAN}

\subsection{Sinopsis}


LINGUA, Vol. 16, No. 1, Maret 2019

p ISSN: 1979 9411; e ISSN: 2442 238X

Http://lingua.pusatbahasa.or.id; Email: presslingua@gmail.com

Center of Language and Cultural Studies, Surakarta, Indonesia

Sultana, Rusdiawan \& Gunayasa, K. Bagus Ida. 2019. Fungsi Cerita Rakyat Sabuk Bidadari dalam Masyarakat Suku Sasak. Lingua (2019), 16(1): 109 122. DOI: 10.30957/lingua.v16i1.578.

\section{Sabuk Bidadari}

Katakan Maaaaan anak-anak ...!!! Dikerubungi anus Acim oleh kuman.

Ini ada satu dongeng yang disebut Sabuk Bidadari. Dikisahkan pada zaman dahulu kala, di puncak Gunung Rinjani, gunung yang paling besar di bumi Lombok, turun sembilan Bidadari dari Kayangan. Bidadari-bidadari itu diceritakan semuanya gadis cantuk baru besar. Sulit akan mencari manusia seperti cantiknya Bidadari.

Pada zaman dahulu kala, ada sembilan orang bidadari dari kayangan turun mandi ke pemandian air panas di Danau Segara Anak yang berada di puncak Gunung Rinjani. Kesembilan bidadari itu memiliki tubuh yang semampai dengan pandangan mata yang teduh. Bulu matanya lentik, hidung mancung, dengan rambut hitam panjang tergerai. Pada saat bidadari turun mandi, mereka diintip oleh seorang Raksasa yang kebetulan lewat disekitar Danau Segara Anak tersebut. Setelah menikmati kehangatan air tersebut para bidadari bergegas keluar ingin segera pulang karena mereka telah merasa cukup mandinya.

Para bidadari keluar dari Danau dan mengambil pakaiannya, ketika itu, salah seorang bidadari merasa bingung karena tidak menemukan pakaian di tempat penyimpanannya, seingatnya pakaiannya betul-betul disimpan di tempat. Mengetahui salah seorang temannya pakaiannya tidak ada di tempat tersebut, mereka pun kembali berendam dan merasa bingung. Pada saat itulah tiba-tiba muncul seorang Raksasa sambil berteriak, "Ambun wong ..., ambun wong...,". Para bidadari merasa ketakutan ketika melihat Raksasa yang sangat menyeramkan. Kemudian Raksasa berkata "Kalau mau mengambil pakaianmu, salah satu dari kalian yang paling cantik harus mau menjadi isteriku," mendengar tawaran dari Raksasa tersebut kesembilan tercengang saling memandang dengan wajah yang penuh dengan ketakutan dan bingung harus berbuat apa, saat itulah salah seorang bidadari yang tertua tiba-tiba memandang wajah Raksasa dengan penuh keberanian dan menyatakan kesiapaannya untuk menjadi isteri Raksasa tersebut.

Sementara itu, di dalam hutan belantara seorang manusia yang gagah perkasa dan tampan bernama Saksakadi sedang bertapa untuk memperoleh kesaktian. Dalam semedinya ia mendengar teriakkan orang-orang yang membutuhkan pertolongan. Teriakkan orang-orang tersebut begitu keras hingga sampai ke telinganya Saksakadi dan suasanan di tempat pertapaan pun menjadi terganggu. Mendengar suara tersebut, muncullah keinginan Saksakadi untuk pergi mencari sumber suara itu. Saat itulah Saksakadi melihat sekelompok Bidadari sedang diancam oleh seorang Raksasa. Melihat kedatangan Saksakadi, Raksasa kembali berteriak "ini makananku, ..., ambun wong..., ambun wong..., ini makananku,".

"Ada apa ini, apa yang terjadi pada kalian?" Saksakadi bertanya. "Diam kamu, kamu tidak tahu apa-apa, kamu tidak boleh mencampuri urusanku", jawab Raksasa dengan geram.

Mendengar jawaban Raksasa tersebut, Saksakadi kembali melontarkan perkataan yang lebih geram lagi, "Eh Raksasa, aku tidak suka mencampuri urusan orang tetapi kamu orang yang bersalah selalu mengganggu orang lain. Dan ini kewajibanku menolong orang yang dalam keadaan susah dan membutuhkan pertolonganku, jadi kamu tidak usah banyak bicara cepatlah pergi dari sini”. 
LINGUA, Vol. 16, No. 1, Maret 2019

p ISSN: 1979 9411; e ISSN: 2442 238X

Http://lingua.pusatbahasa.or.id; Email: presslingua@gmail.com

Center of Language and Cultural Studies, Surakarta, Indonesia

Sultana, Rusdiawan \& Gunayasa, K. Bagus Ida. 2019. Fungsi Cerita Rakyat Sabuk Bidadari dalam Masyarakat Suku Sasak. Lingua (2019), 16(1): 109 122. DOI: 10.30957/lingua.v16i1.578.

Mendengar ucapan Saksakadi darah Raksasa itu menjadi panas, ingin segera memotong dan mencabik-cabik wajahnya Saksakadi, tak lama kemudian Raksasa dengan keperkasaannya langsung menyerang Saksakadi secara babibuta dan Saksakadipun sudah siap menghadapi serangan dari Raksasa sehingga terjadilah perkelahian yang sangat sengit antara Saksakadi dengan Raksasa.

Perkelahian terus berlanjut, jurus demi jurus dikeluarkan oleh keduannya baik oleh Saksakadi maupun Raksasa, sehingga sampai berjam-jam yang akhirnya keduanya sama-sama kuat, jurus demi jurus telah berlalu, ilmu yang dimiliki oleh keduanya sama-sama kuat dan seimbang, dan tidak ada yang kalah ataupun menang. Ketika itu seorang Bidadari mendapat akal untuk menolong Saksakadi. Bidadari itu mengeluarkan selembar kain yang berwarna keemasan, kemudian kain itu diarahkan ke sinar matahari yang hampir tenggelam saat itu. Pantulan sinar itu di arahkan ke muka Raksasa agar matanya menjadi silau. Tidak lama kemudian Raksasa itu mulai kewalahan dan menjadi lengah. Di saat itulah Saksakadi menusuk dada Raksasa persis pada jantungnya hingga tak bernafas lagi.

Setelah Raksasa tak bernafas lagi atau mati, Saksakadi dan kesembilan Bidadari merasa bebas dari gangguan dan ancaman Raksasa. Para Bidadari pulang ke Kayangan. Namun demikian, melihat kegantengan dan keperkasaan Saksakadi seorang Bidadari yang paling cantik jatuh hati pada Saksakadi, begitu pula sebaliknya Saksakadi jatuh hati pada bidadari itu. Kedua insan itu ingin memeluk gunung, namun apa daya tangan tak sampai, karena antara Saksakadi dengan Bidadari itu memiliki dunia yang berbeda dan sulit untuk dapat bersatu menjadi suami isteri. Oleh karena itu, dengan sangat terpaksa Bidadari itu pulang ke kayangan dengan rasa berat hati dan kesedihan yang mendalam.

Sebelum para bidadari itu berangkat ke kayangan, salah seorang bidadari yang paling cantik berpesan pada Saksakadi "Untuk membuktikan cinta kasihku kepada Kakang, menengadahlah ke langit bila hujan reda. Lihatlah bentangan kain atau seluruh pakaianku akan aku jemur dan air yang jatuh ke bumi adalah air mata kesedihanku."

Setelah mengucapkan kata-kata itu, berangkatlah Bidadari itu dengan langkah berat ke negerinya. Negeri Kayangan, tempat kediaman para dewa dewi. Melihat kepergian Bidadari itu Saksakadi diam tercengang tanpa dapat berkata sepatah kata pun.

\subsection{Analisis Fungsi Cerita Sabuk Bidadari}

Dari pengamatan sepintas, dapat ditentukan beberapa fungsi yang berhubungan dengan cerita rakyat "Sabuk Bidadari”, yakni:

1) Sebagai sistem proyeksi, yaitu alat pencerminan angan-angan secara kolektif.

Mite ini disamping sebagai sebuah ajang hiburan bagi anak-anak pada saat senggang, juga sebagai pencerminan angan-angan. Bila kita mendengar ceritanya seakan-akan angan-angan kita terbawa ke dalam cerita tersebut, seolah-olah kita yang mengalami dan yang menjadi tokoh di dalam cerita itu. Jika dalam cerita tersebut situasi tegang kita ikut tegang, sebaliknya jika situasinya sedih kita ikut sedih. Seolah-olah kita melihat dan mengalami cerita tersebut. 
LINGUA, Vol. 16, No. 1, Maret 2019

p ISSN: 1979 9411; e ISSN: 2442 238X

Http://lingua.pusatbahasa.or.id; Email: presslingua@gmail.com

Center of Language and Cultural Studies, Surakarta, Indonesia

Sultana, Rusdiawan \& Gunayasa, K. Bagus Ida. 2019. Fungsi Cerita Rakyat Sabuk Bidadari dalam Masyarakat Suku Sasak. Lingua (2019), 16(1): 109 122. DOI: 10.30957/lingua.v16i1.578.

2) Sebagai alat pendidikan

Hingga sekarang mite ini masih digunakan oleh orang-orang tua, pemuka agama, pemuka adat, ataupun pemimpin suku sebagai bahan untuk menyebarkan nilainilai luhur budaya nusantara pada umumnya dan suku Sasak Lombok pada khususnya. Nilai-nilai luhur budaya berisi ajaran dan nilai-nilai yang akan menjadi pedoman dan penuntun hidup, sehingga dalam menjalani hidup, orang akan bersikap hati-hati agar terhindar dari sikap dan perbuatan yang melanggar norma, adat, tata susila dan kaidahkaidah yang berlaku dalam masyarakat.

Hal ini tergambar pada kehidupan tokoh Saksakadi yang menjunjung tinggi normanorma kehidupan, sebagai berikut:

Dalam semedinya ia mendengar teriakkan orang-orang yang membutuhkan pertolongan. Pergilah ia mencari sumber suara itu. Saksakadi melihat sekelompok Bidadari sedang diancam oleh seorang Raksasa. Melihat kedatangan Saksakadi, Raksasa kembali berteriak "ini makananku, ..., ambun wong..., ambun wong..., ini makananku,".

"Ada apa ini, apa yang terjadi pada kalian?" Saksakadi bertanya. "Diam kamu, kamu tidak tahu apa-apa, kamu tidak boleh mencampuri urusanku”, jawab Raksasa dengan geram.

"Eh Raksasa, aku tidak suka mencampuri urusan orang tetapi kamu orang yang bersalah selalu mengganggu orang lain. Dan ini kewajibanku menolong orang yang dalam keadaan susah dan membutuhkan pertolonganku, ....

Dari kutipan cerita di atas menggambarkan adanya nilai pendidikan yang sangat bermanfaat sebagai modal untuk menjalani suatu interaksi dalam masyarakat tanpa tanpa meninggalkan aturan-aturan atau norma yang berlaku. Di antara nilai pendidikan dari kutipan di atas, yaitu:

a. Adanya motivasibesar yang dimiliki oleh Saksakadi untuk mendapatkan ilmu.

b. Adanya sifat suka menolong kaum lemah atau orang-orang yang membutuhkannya,

c. Tidak mau mencampuri urusan orang lain berdasarkan aturan atau norma yang berlaku.

3) Sebagai alat kritik

Mite ini dapat digunakan sebagai sarana untuk mengkritik para penguasa yang sewenang-wenang (otoriter). Para penguasa yang sewenang-wenang dilambangkan dengan Raksasa dan perilakunya dalam kutipan cerita berikut:

... Mengetahui pakaiannya tidak ada di tempat, mereka pun kembali berendam dan merasa bingung. Pada saat itulah muncul Raksasa sambil berteriak, "Ambun wong ..., ambun wong...,". Para bidadari merasa ketakutan ketika melihat Raksasa yang sangat menyeramkan. Kemudian Raksasa berkata "Kalau mau 
LINGUA, Vol. 16, No. 1, Maret 2019

p ISSN: 1979 9411; e ISSN: 2442 238X

Http://lingua.pusatbahasa.or.id; Email: presslingua@gmail.com

Center of Language and Cultural Studies, Surakarta, Indonesia

Sultana, Rusdiawan \& Gunayasa, K. Bagus Ida. 2019. Fungsi Cerita Rakyat Sabuk Bidadari dalam Masyarakat Suku Sasak. Lingua (2019), 16(1): 109 122. DOI: 10.30957/lingua.v16i1.578.

mengambil pakaianmu, salah satu dari kalian yang paling cantik harus mau menjadi isteriku"

Kutipan cerita di atas menggambarkan bahwa, Raksasa memiliki sifat serakah, tamak, sombong, egois dan merasa diri maha kuat sehingga menimbulkan kesengsaraan orang lain (bidadari). Oleh karena itu sifat yang demikian harus dimusnahkan dari bumi pertiwi.

4) Sebagai Pelipur Lara

Mite ini digunakan sebagai sebuah ajang hiburan bagi anak-anak pada saat senggang. Biasanya cerita ini diceritakan oleh orang tua untuk mengisi waktu kosong, seperti kakek-kakek atau orang yang khusus menggauli cerita rakyat. Dan pecerita dikelilingi oleh anak-anak atau orang-orang yang mendengarkan cerita yang sedang dibawakan.

\section{Simpulan}

Berdasarkan sajian dan pembahasan di atas disimpulkan bahwa dalam cerita "Sabuk Bidadari" terdapat lima fungsi. Fungsi cerita "Sabuk Bidadari" yaitu: (1) Sebagai sistem proyeksi, yaitu alat pencerminan angan-angan secara kolektif, (2) Sebagai alat pendidikan, (3) Sebagai alat kritik, dan (5) Sebagai alat pelipur lara.

\section{DAFTAR PUSTAKA}

Alwi, Hasan. 2001. Kamus Besar Bahasa Indonesia. Jakarta: PN. Balai Pustaka.

Arikunto Suharsimi. 2002. Prosedur Penelitian Suatu Pendekatan Praktik. Jakarta: Rineka Cipta

Bascom. 1985. Sari Sastra Indonesia. Jakarta: Pustaka Utama.

Danandjaja , James. 1997. Folklor Indonesia (Ilmu gosip, dongeng dan lain-lain

Cet. V. Jakarta: Pustaka Utama Grafiti

Dwiyanto Setiawan. 2000. Cerita Rakyat dari Jawa Timur. Jakarta: Gramedia Widiasarana Indonesia.

Emzir dan Saifur Rohman. 2016. Teori dan Pengajaran Sastra. Jakarta: Rajawali Pers

Endraswara, Suwardi. 2013. Metodologi Penelitian Sastra: Epistimologi, Model,

Teori, dan Aplikasi. Yogyakarta: CAPS (Center for Academic Publishing Service)

Fauzan. 2014. Pengantar Filsafat Ilmu (Edisi Revisi). Mataram: Arga Puji Press

Jabrohim. 2015. Teori Penelitian Sastra. Yogyakarta: Pustaka Pelajar

Koentjaraningrat. 2004. Manusia dan Kebudayaan. Jakarta: Djambatan

Kuntarto, Niknik M. 2013. Cermat dalam Berbahasa Teliti dalam Berpikir (Edisi

Keempat). Jakarta: Mitra Wacana Media

Kuswarno Engkos, 2008. Metode Penelitian Etnografi Komunikasi. Bandung. Widya

Padjajaran. 
LINGUA, Vol. 16, No. 1, Maret 2019

p ISSN: 1979 9411; e ISSN: 2442 238X

Http://lingua.pusatbahasa.or.id; Email: presslingua@gmail.com

Center of Language and Cultural Studies, Surakarta, Indonesia

Sultana, Rusdiawan \& Gunayasa, K. Bagus Ida. 2019. Fungsi Cerita Rakyat Sabuk Bidadari dalam Masyarakat Suku Sasak. Lingua (2019), 16(1): 109 122. DOI: 10.30957/lingua.v16i1.578.

Kosasi. 2008. Ensiklopedia Sastra Indonesia. Jakarta: Nobel Edumedia.

Mahsun. 2017. Metode Penelitian Bahasa: Tahapan, Strategi, Metode, dan tekniknya. Depok: Rajawali Pers

Nurgiyantoro, Burhan. 2013. Sastra Anak (Pengantar Pemahaman Dunia Anak).

Yogyakarta: Pustaka Pelajar

Nurgiyantoro, 2009. Teori Penelitian Fiksi, Yagyakarta: Gadja Mada University Press.

Nurhayati. 1999. Antologi Sastra Daerah Nusantara, Cerita Rakyat Suara Rakyat, Jakarta: Yayasan Obor Indonesia.

Nuriadi. 2016. Theory of Literature an Inroduction. Mataram: Arga Puji Press

Partanto. 1994. Kamus Kecil Bahasa Indonesia. Surabaya: Penerbit Arkola.

Porwadarminta. 1988. Kamus Umum Bahasa Indonesia. Jakarta: Balai Pustaka

Pradopo, Rachmat Djoko. 2012. Beberapa Teori Sastra, Metode Kritik, dan Penerapannya. Yogyakarta: Pustaka Pelajar

Ratna, Nyoman Kutha. 2010. Sastra dan Cultural Studies (Repesentasi Fiksi dan Fakta). Yogyakarta: Pustaka Pelajar

Ratna, Nyoman Kutha. 2011. Antropologi Sastra (Peranan Unsur-Unsur Kebudayaan dalam Proses Kreatif). Yogyakarta: Pustaka Pelajar

Ratna, Nyoman Kutha. 2015. Teori, Metode dan Teknik Penelitian Sastra Cetakan XIII. Yogyakarta: Pustaka: Pelajar

Ratna, Nyoman Kutha. 2015.Estetika Sastra dan Budaya. Yogyakarta: Pustaka Pelajar

Riyanto Yatim. 2001. Metodologi Penelitian Pendidikan. Surabaya: Penerbit SIC.

Samsuri, 2006. Kamus Lengkap Bahasa Indonesia Modern. Surabaya: Greisinda Pres.

Saridjo, Marwan. 2006. Sastra dan Agama (Tinjauan Kesusastraan Indonesia Modern Bercorak Islam. Jakarta: Penamadani

Sastre, Jean-Paul. 2010. Theory of the Emotions (Mengungkap Sketsa Emosi dan Humanisme

Semi, Atar. 2013. Kritik Sastra Edisi Revisi. Bandung: Agkasa

Sibarani, Robert. 2015. Pembentukan Karakter (Langkah-Langkah Berbasis Kearifan Lokal. Jakarta: Asosiasi Tradisi Lisan

Siswantoro. 2010. Metode Penelitian Sastra (Analisis Struktur Puisi).

Yogyakarta: Pustaka Pelajar

Sudaryanto. 2016. Cerdas Menulis Karya Ilmiah. Yogyakarta: Sanata Dharma University Press

Sugiyono. 2013. Metode Penelitian Kuantitatif Kualitatif dan R\&D. Bandung: AlfaBeta

Sudjana dan Ibrahim. 2004. Penelitian dan Penilaian Pendidikan. Bandung: Sinar Baru Algesindo.

Sulhan Najib. 2006. Piramida Bahasa Indonesia. Surabaya: Penerbit SIC.

Suyatno. 2004. Teknik Pembelajaran Bahasa dan Sastra, Surabaya : SIC

Tarigan, Henry Guntur. 1985. Prinsip-Prinsip Dasar Sastra. Bandung: Angkasa

Thomas, Linda dan Shan Wareing. 2007. Bahasa, Masyarakat, dan Kekuasaan. Yogyakarta: Pustaka Pelajar 
LINGUA, Vol. 16, No. 1, Maret 2019

p ISSN: 1979 9411; e ISSN: 2442 238X

Http://lingua.pusatbahasa.or.id; Email: presslingua@gmail.com

Center of Language and Cultural Studies, Surakarta, Indonesia

Sultana, Rusdiawan \& Gunayasa, K. Bagus Ida. 2019. Fungsi Cerita Rakyat Sabuk Bidadari dalam Masyarakat Suku Sasak. Lingua (2019), 16(1): 109 122. DOI: 10.30957/lingua.v16i1.578.

Ullman, Stephen. 2014. Pengantar Semantik (Diadaptasikan oleh Sumarsono). Yogyakarta: Pustaka Pelajar

Wijana, I Dewa Putu. 2011. Semantik (Teori dan Analisis). Surakarta: Yuma Pustaka

Wijana, I Dwa Putu. 2015. Pengantar Semantik Bahasa Indonesia. Yogyakarta:

Pustaka Pelajar

Zaidan, Abdul Rozak dkk. 1996. Kamus Istilah Sastra Jakarta: Balai Pustaka 